\title{
QUATERNARY CALCARENITE ("POROS") OF MYKONOS, DELOS AND RHENIA, CYCLADES ISLANDS, GREECE
}

Varti-Mataranga M. ${ }^{1}$ and Piper W.J.D. ${ }^{2}$

${ }^{1}$ Institute of Geological \&Mineral Exploration (IGME), Messogion 70, Athens 11527, Greece, myrsini@igme.gr,myrsini@otenet.gr.

${ }^{2}$ Geological Survey of Canada (Atlantic), Bedford Institute of Oceanography, P.O. Box 1006, Dartmouth, N.S., B2Y 4A2, Canada, piper@agc.bio.ns.ca.

\section{ABSTRACT}

Outcrops of friable calc-arenite of late Quaternary age, known as Poros rock, from Mykonos, Rhenia and Delos, are characterized sedimentologically and their cements are studied in thin section. Calcarenites of beach, coastal eolian dune, and pedogenic alluvium origin are distinguished sedimentologically. Beach calcarenite shows marine cementation by a uniform rim of micrite and bladed Mg-calcite. Some eolian dunes show precipitation of needle aragonite, probably from sea spray, but the dominant cements are sparry calcite from groundwater and vadose zone deposition of irregular micrite with meniscus and gravitational textures. Pedogenically cemented alluvium shows the characteristics of caliche, such as rhizoliths with clots and globules of micrite and circumgranular cracking. One outcrop of calcarenite from Panormos Bay in Mykonos shows beach facies at +2.5 to $+4.0 \mathrm{~m}$ above present sea level, overlying cemented debris flow deposits. This occurrence is interpreted as Tyrrhenian in age (isotopic stage $5 \mathrm{e}$ ) and implies regional long-term subsidence of $2 \mathrm{~cm} / \mathrm{ka}$, consistent with the lack of marine terraces in the area. Archeological sites on Delos show irregular variations of sea level of about $1 \mathrm{~m}$ in the past $2.5 \mathrm{ka}$, probably related to movement on faults.

\section{INTRODUCTION}

Poros rock is a lightly cemented, friable calcarenite or calcareous sandstone of Quaternary age that was widely used as a building stone in antiquity. It is widespread in the Cyclades (Fytrolakis \& Papanikolaou 1977) and was first called "Poros of Cyclades" by Cayeux (1907), who described outcrops on the small islands of Delos and Rhenia (Fig. 1). Occurrences on the larger island of Mykonos were first described by Boblaye \& Virlet (1833). Philippson (1898) and later by Keraudren (1970).

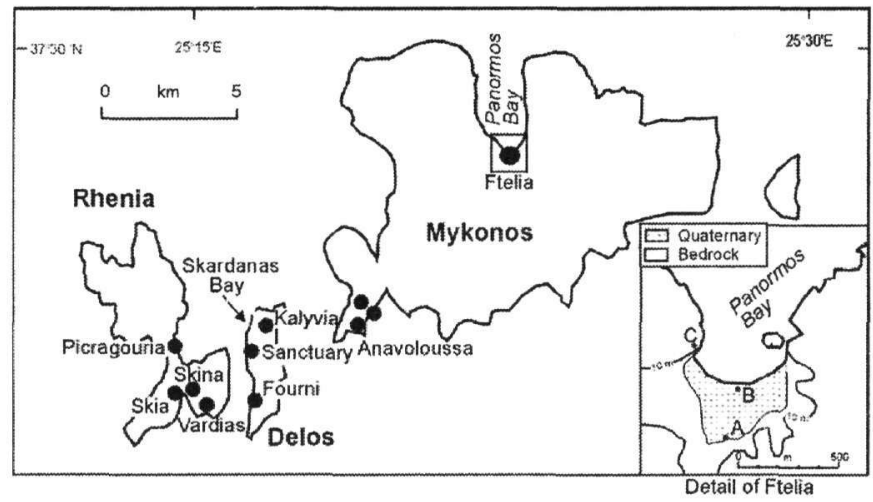

Fig. 1. Map of Mykonos and adjacent islands in the southern Aegean Sea showing location of calcarenite outcrops. Inset shows Panormos Bay and location of sections A, B and C (Fig. 2). 
Calcarenite occurs at elevations of up to $80 \mathrm{~m}$ above present sea level in the Cyclades, although most occurrences are near the present coastline. Most calcarenite is of coastal marine origin, containing marine fossils, but some is of eolian origin (Mistardis 1933). Although Philippson (1901) identified a Pliocene fossil in calcarenite in Mykonos, later authors have been unable to duplicate this observation and have regarded Poros calcarenite as early Holocene (Voreadis 1961) or Pleistocene (Keraudren 1970).

The objective of this paper is to determine the depositional environments of the calcarenites known as Poros by study of all the known occurrences on the islands of Mykonos, Rhenia and Delos. We demonstrate that field sedimentological observations and thin-section studies of cements can be used to determine the original depositional environment. Such observations may be of value in determining the sources of Poros building stones in archeological sites.

\section{FIELD STRATIGRAPHY AND SEDIMENTOLOGY}

\subsection{Mykonos}

The best developed calcarenite outcrops in Mykonos are at Ftelias, at the head of Panormos Bay in the northern part of the island. A $0.5 \mathrm{~km}$ long sandy beach is interrupted by a rocky outcrop of calcarenite that forms a terrace about $5 \mathrm{~m}$ above sea level (asl) (B in Fig. 1 inset and Fig. 2). The archeological site of Aianta's tomb is located on this terrace. The top of this section shows welldeveloped cross-bedded sets, with sets up to $1 \mathrm{~m}$ thick and dip angles of up to $25^{\circ}$. The size of the sets and the excellent sorting of the sands indicates an eolian origin. These cross-bedded sands show a small amount of bioturbation. Underlying sands show vestiges of cross-bedding but are more intensely bioturbated. The dominant bioturbation consists of 1-2 cm diameter burrows (similar to those at the top of Fig. 3a) which resemble those of modern land crabs.
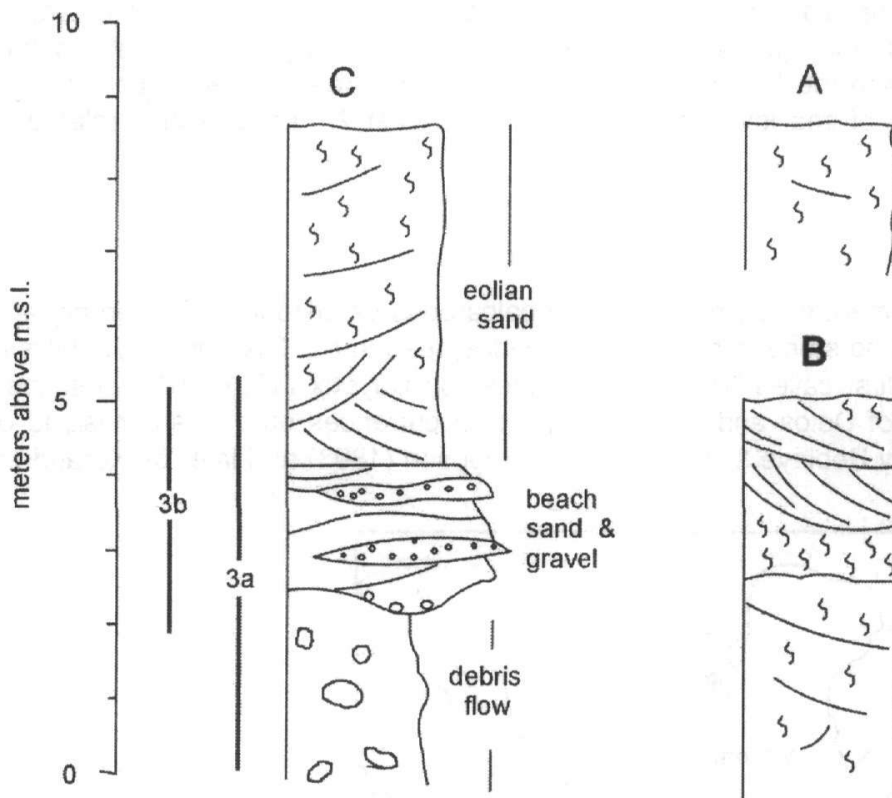

\section{B}

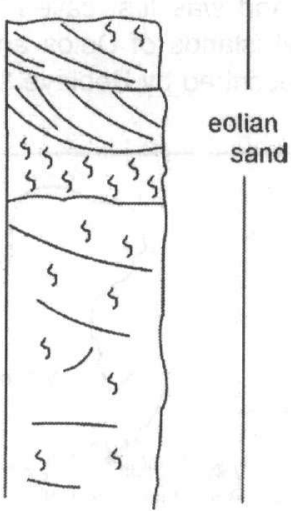

S s bioturbation OO clasts

Fig. 2. Stratigraphic sections from Panormos Bay, Mykonos. 
A few hundred meters inland, there is an area of calcarenite up to $8 \mathrm{~m}$ asl ( $\mathrm{A}$ in Figs. 1, 2), similar to the highly bioturbated eolian sandstones described above, but less well cemented. Old quarries for Poros rock are located here. The area is partly covered by modern eolian sands with sparse vegetation.

On the west side of Panormos Bay (C in Figs. 1, 2), a red muddy sand with dispersed gravel and local gravel layers outcrops at present sea level (Fig. 3a). This unit has the sedimentological character of debris-flow deposits. It is overlain at $+2.5 \mathrm{~m}$ asl by a $1.5 \mathrm{~m}$ thick unit of bedded coarse to medium sand, a few pebbles and two lenses of red muddy sand similar to the underlying unit. This unit exhibits rather irregular large-scale low-angle cross bedding, with a cut and fill character (Fig. 3b). The sedimentological features of this unit are similar to those seen on the nearby modern pocket beach, where debris-flow deposits periodically flow onto the beach from the adjacent cliff. The uppermost unit comprises about $4 \mathrm{~m}$ of eolian calcarenite, with large-scale cross bedding and characteristic bioturbation.
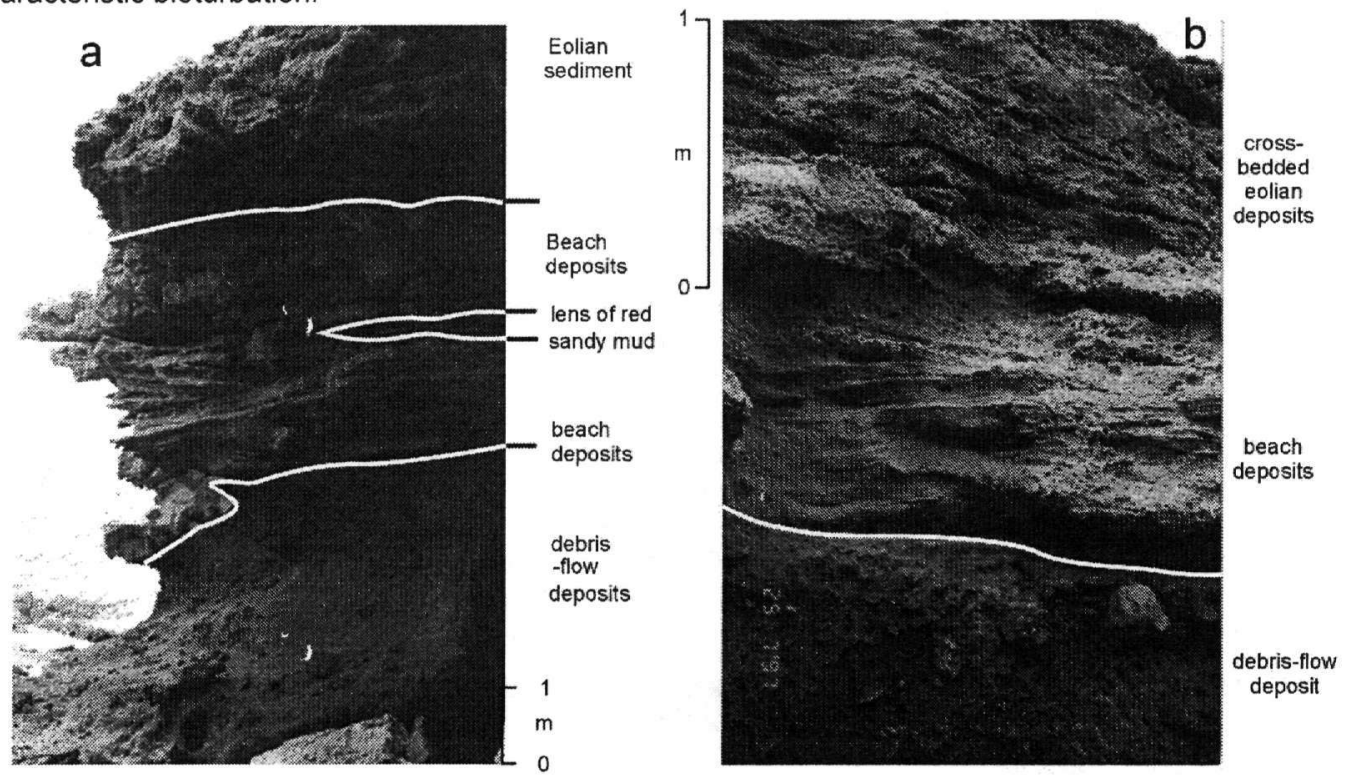

Fig. 3. Photographs field occurrence of calcarenite. (a) general view of section C from Panormos Bay, Mykonos, showing basal debris-flow unit overlain by beach sands with debris-flow lenses and capped by bioturbated eolian deposits. (b) detail of beach sand unit showing low-angle cross-stratification.

Keraudren (1970) des:cribed small outcrops of calcarenite from the Anavoloussa peninsula in southwest Mykonos. At two localities, pebbly sand of local derivation from granite bedrock is overlain at 5-7 $\mathrm{m}$ asl by calcarenite of eolian origin.

\subsection{Delos}

The small island of Delos in classical times was a major religious centre with the main buildings in the Sanctuary of Apollo dating from the 5-6th centuries BC. Later, in the 1-2nd centuries BC (Hellenistic period), Delos was a flourishing commercial centre with a town build south of the Sanctuary. A considerable part of the coast west of the Sanctuary and town is built of historic landfill. Archeological evidence suggests that at the time the Lion Terrace was built at the end of the 7th century $B C$, sea level was about $1 \mathrm{~m}$ higher than at present (Chadzidakis, pers. comm. 1999). Hellenistic buildings near Skardanas Bay suggest sea level $0.3 \mathrm{~m}$ above present in the first century BC (ibid). At the present time, some coastal archeological buildings are submerged by up to $1.5 \mathrm{~m}$, implying differential subsidence along the west coast of Delos. We consider this recent subsidence to be most likely the result of progressive compaction of the historic landfill. 
Poros rock was reported as quite widespread by Cayeux (1911) on the main archeological site of Delos, presumably revealed by excavation, but we were able to find only a small outcrop about $50 \mathrm{~cm}$ asl in the Sanctuary of Apollo. This is a poorly stratified calcarenite containing marine fossils. More extensive outcrops are found at Kalyvia in the centre of the island at about $12 \mathrm{~m}$ asl, notably in an old quarry where the section is about $1.5 \mathrm{~m}$ thick. This Poros rock is an impure calcareous mudstone with considerable secondary porosity, with some low angle cross stratification of uncertain origin. Cayeux (1911) also described Poros rock inland from Fourni; this outcrops at elevations of $10-20 \mathrm{~m}$ asl and consists of sandy alluvium, locally with pedogenic carbonate cement (calcrete). This alluvium also contains cultural remains, suggesting a late Holocene age.

\subsection{Rhenia}

In central Rhenia, calcarenite of eolian origin with large scale cross bedding and bioturbation similar to that at Panorme $s$ Bay on Mykonos is found up to $+2 \mathrm{~m}$ asl in Schina and Skia bays (Fig. 1). In addition, calcrete-type Poros rock, similar to that at Fourni on Delos, is found between Vardias and Picragouria.

\section{PETROGRAPHY}

Calcarenite of beach origin from section $\mathrm{C}$ at Panormos is a moderately sorted coarse to very coarse grained impure calcarenite, with $40 \%$ terrigenous grains, principally quartz, feldspar and granite fragments, but including some dark red lithoclasts from the underlying debris flow deposits. The carbonate grains are well rounded, typically $0.6 \mathrm{~mm}$ but up to $2.5 \mathrm{~mm}$ diameter, comprising fragments of red algae, mollusc shells, echinoderms, foraminifera, bryozoa, and gastropods. The grains are coated by a thin micritic rim overlain by a uniform layer of bladed (Mg-calcite) cement (Fig 4A). Micritic cement predominates between the grains, but remaining pores are rimmed mainly by equant spar calcite cement with peloids (Fig. 4A) and rarely by needle-fibrous aragonite cement (Fig. 4B). Locally, caliche characteristics such as rhizoliths with clotted micrite, globules, and circumgranular cracking is observed (Fig. $4 \mathrm{C}$ ). The cementation sequence is interpreted as (1) marine (uniform micritic rim and blades of Mg-calcite); (2) subaerial (micrite between the grains and rhizoliths); and (3) phreatic fresh water (equant spar) and marine aerosols (needle fibrous).
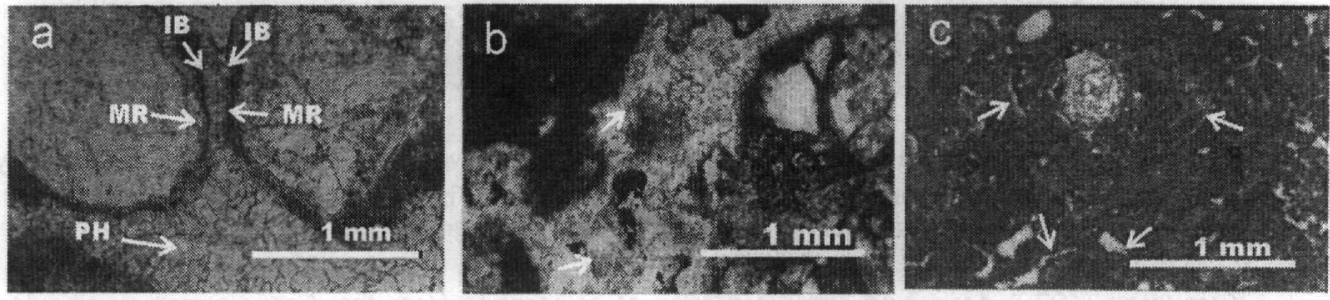

Fig. 4. Photomicrographs of calcarenite from beach facies in section $\mathrm{C}$ at Panormos. (All photomicrographs with //polars). A: showing cementation sequence of micritic rim (MR), partly dissolved isopachous bladed cement (IB), indicating a marine environment, equant spar $(\mathrm{PH})$ indicating a phreatic environment [LMF7, x140]. B: showing needle fibrous aragonite cement (marine aerosols) (indicated by arrows) [LMF7, x140]. C: showing rhizolith with circum-granular cracking indicated by arrows [LMF7, x140].

Eolian calcarenite from section $\mathrm{C}$ at Panormos is a well sorted, very coarse grained $(0.6-0.9$ $\mathrm{mm}$ ) impure calcarenite, consisting of $50 \%$ well-rounded carbonate grains. Their composition is similar to that of beach calcarenite described above, except that dark red lithoclasts are lacking. The grains are coated by thin micritic rim and subsequently by fibrous aragonite cement, partly dissolved. Locally meniscus cement and equant spar calcite cement are observed.

Eolian calcarenite from section B at Panormos is a moderately sorted, coarse grained $(0.6 \mathrm{~mm})$ calcarenite with $50-60 \%$ well rounded carbonate grains. The grains are only slightly cemented, with a thin micritic rim. Locally, meniscus, gravitational (Fig. 5A) and equant spar calcite cement are common. 

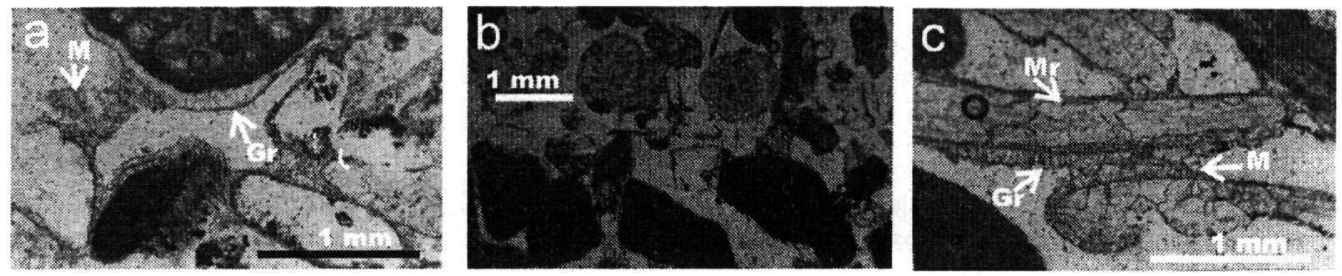

Fig. 5. Photomicrographs of calcarenite from sections $B$ and $A$ at Panormos. A: Calcarenite from section $B$, showing gravitational (Gr) and meniscus (M) cement [LMF1, x140]. B: Calcarenite from section A, showing general character of calcarenite including the small degree of cementation [LMF3, x55]. C: Calcarenite from section $A$, showing very thin micritic rim (Mr) coating grains, subsequently cemented by meniscus $(M)$ and gravitational (Gr) cement [LMF3, x140].

Eolian calcarenite from section $\mathrm{A}$ at Panormos is moderately sorted, coarse to medium grained calcarenite with $50-60 \%$ well-rounded carbonate grains and sub-angular to sub-rounded noncarbonate grains (Fig. 5B). The degree of cementation is small. Meniscus cement between grains and gravitational cement are common (Fig. 5C).

The calcarenite from Delos town archeological site is a well sorted, grain supported, coarse to very coarse grained $(0.9-1.5 \mathrm{~mm})$ impure calcarenite $(65 \%$ well rounded carbonate grains; lithoclasts of granite, and feldspar, quartz and biotite) (Fig. 6A). The grains are coated by thin micritic rim, subsequently by fikrous aragonite cement and finally by a brown iron oxide/hydroxide rich in $\mathrm{Al}$ (?including clays). The inıpure calcareous mudstone from Kalyvia contains sparse marine fossils (foraminifera, sponge spicules, gastropods) and has undergone intense calichification. It may have originally formed in a lagoonal environment. The pedogenically cemented alluvium (calcrete) from Fourni shows rhizoliths characteristics of caliche.
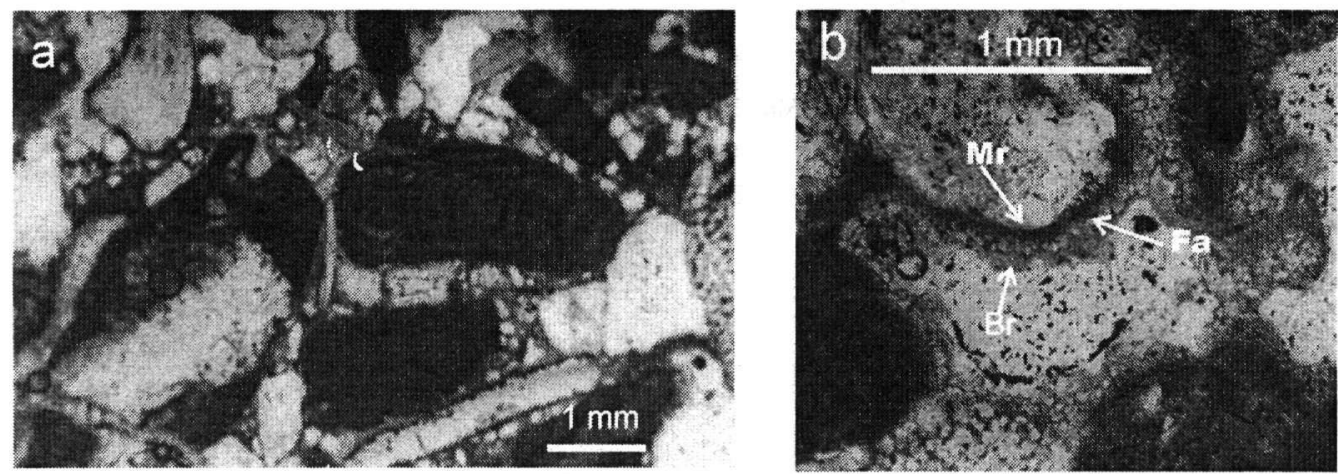

Fig. 6. Photomicrographs of salcarenite from Delos town archeological site. A: General character of Delos calcarenite sample [Del, $\times 55$ ]. B: Grains coated by thin micritic rim (Mr) and subsequently by fibrous aragonite cement $(\mathrm{Fa})$ and finally by brownish ?iron hydroxides $(\mathrm{Br})[\mathrm{Del}, \mathrm{x} 140]$.

The eolian calcarenite from Rhenia is a well sorted, coarse grained $(0.6 \mathrm{~mm})$ impure calcarenite, generally with $75-80 \%$ carbonate grains (exceptionally $55 \%$ ), with non-carbonate grains similar to those of Delos. The grains are covered by micritic cement of irregular thickness, commonly of the meniscus type (suggesting vadose conditions). Subsequently, small equant sparry calcite cement (meteoric origin) formed in interparticle spaces as well as needle-fibre cement type (vadose) and rare gravitational cement. The calcarenite from Schina is locally calichefied.

In summary, all the Poros calcarenite samples have a similar primary composition, but show striking differences in cementation. The calcarenite of beach origin shows clear marine cementation, with micritic rims and uniform bladed Mg-calcite cement. Samples from sections B and C at Panormos, that would receive large amounts of spray during storms, also show marine influence, with needle-like aragonitic cement over the micritic rims. Samples from section A at Panormos, 
Delos and Rhenia show principally subaerial cementation, with equant sparry calcite (groundwater) and meniscus and gravitational micritic cement (vadose conditions).

\section{DISCUSSION}

The observations on modern eolian dunes in Panormos Bay show that eolian calcarenite can form at least $8 \mathrm{~m}$ above contemporary sea level and may contain transported and abraded marine fossils. On the other hand, well-developed beach facies in stratigraphic context, such as in section $\mathrm{C}$ in Panormos Bay, are an excellent indicator of past sea level, in this case at +3 to $+4 \mathrm{~m}$ above modern sea level. Although exceptionally in the Aegean, Holocene raised beaches are found as high as $+3 \mathrm{~m}$ (Pirazzolli et al. 1989), the occurrence of thick dunes in section C, which is now cliffed, and the induration of the debris-flow deposits makes a Holocene age very unlikely. Furthermore, the Cyclades are not a seismically very active area. Raised terraces are generally lacking on the coastline of Mykonos, suggesting that there has not been significant net uplift in the late Quaternary, in contrast, for example, with the Peloponnese (Kelletat et al. 1978).

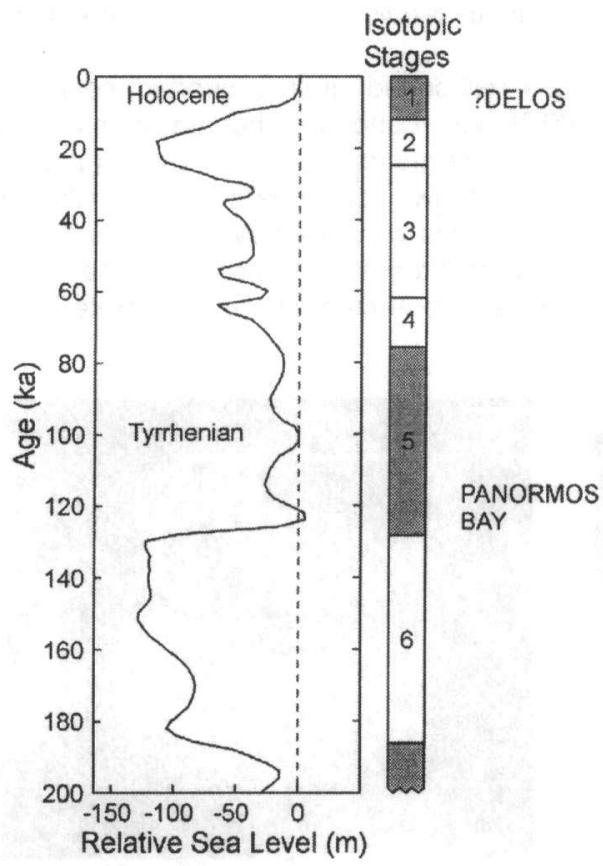

Fig. 7. Interpretation of the Panormos Bay and Delos town sections in terms of late Quaternary sea-level history (Eustatic relative sea level curve from Skene et al. 1998).

The beach deposits at section $\mathrm{C}$ appear to be the highest marine deposits in Panormos Bay. We suggest that the simplest interpretation is that they date from the Tyrrhenian maximum highstand of sea level at about $125 \mathrm{ka}$ (isotopic stage $5 \mathrm{e}$ ), when globally sea level was about $6 \mathrm{~m}$ above its present level, implying slow net subsidence (about $2 \mathrm{~cm} / \mathrm{ka}$ ) of the coastline of northern Mykonos (cf. Cayeux, 1907). Were the beach in section $C$ younger than Tyrrhenian, then it would be surprising that no evidence is seen for a Tyrrhenian maximum highstand of sea level. Were the beach older than Tyrrhenian, then again, some evidence of the Tyrrhenian maximum highstand would be expected. Shackleton (1987) has shown that the Tyrrhenian was probably the highest stand of sea level in at least the past $0.5 \mathrm{Ma}$, with sealevel lower than in the Holocene in isotopic stages 7 and 9 and at about Holocene levels in stages 11 and 13.

The eolian calcarenite in sections A and B probably imply sea level within $5 \mathrm{~m}$ of its present level. Although it thus could be of middle Holocene age, the widespread distribution of the eolian 
calcarenite suggests a prolonged period of formation, perhaps during the Tyrrhenian interglacial from $85-128 \mathrm{ka}$ when sea level fluctuated but was generally within +5 to $-10 \mathrm{~m}$ of its present level (Skene et al. 1998).

The lack of clear beach facies in Delos and Rhenia and the occurrence of eolian calcarenite in Rhenia and marine calcarenite in Delos close to present sea level makes interpretation of age difficult. Where coastlines are close to major normal faults, fluctuations of sea level of up to $2-3 \mathrm{~m}$ may take place over a few thousands of years in response to seismic activity along the fault (Jackson \& McKenzie 1983; Pirazzolli et al. 1989). For example, in Evia, ancient harbours lie < $1.8 \mathrm{~m}$ below present sea level but raised notches indicate late Holocene sea levels up to $1.1 \mathrm{~m}$ above present sea level (Stiros et al. 1992). Fluctuations in sea-level recorded by calcarenite in the Delos Sanctuary and Rhenia are within these limits and thus the calcarenite could be of Holocene age. Alternatively, a Tyrrhenian interglacial age, as inferred for Panormos Bay, is equally possible. The elevation of the ?lagoonal calcareous mudstone at Kalyvia in Delos at $+12 \mathrm{~m}$ above present sea level can be accounted for if it is of Tyrrhenian stage $5 \mathrm{e}$ age and there has been some local movement along faults defining the present deep-water channel between Mykonos and Delos.

\section{CONCLUSIONS}

Calcarenite deposits known as Poros in northern Mykonos and Rhenia are principally of eolian facies, with some beach and minor lagoonal facies. The facies can be distinguished by their sedimentary structures and the nature of the cements. Beach facies have uniform micrite and bladed $\mathrm{Mg}$-calcite rims over carbonate grains. Eolian facies have cements of sparry calcite (from groundwater), irregular meniscus and gravitational micritic cements (from vadose conditions) and in some cases needle aragonite (precipitated from marine spray).

In northern Mykonos, beach facies calcarenite unconformably overlies red debris-flow deposits at +2.5 to $+4 \mathrm{~m}$ as and is interpreted to represent the Tyrrhenian maximum highstand of sea level, implying slow long-term subsidence of the coastline at about $2 \mathrm{~cm} / \mathrm{ka}$.

\section{REFERENCES}

Boblaye P. and Virlet Th. 1833. Expédition scientifique de Morée. II: Géologie et Minéralogie. Paris.

Cayeux L. 1907. Fixité du niveau de la Méditerranée à l'époque historique (Delos, Crete). Annales de Géographie 16, 97-116.

Cayeux L. 1911. Description physique de l'île de Délos. Exploration Archéologique de Délos, Fontemoing et Cie, Paris.

Fytrolakis N. and Papanikolaou D. 1977. Some new occurrences of quaternary sandstones in the Cyclades and their paleogeographic importance. 6th Colloquium on the Geology of the Aegean region (Athens, 1977) 1 . 459-467.

Jackson J. and McKenzie D.P. 1983. The geometrical evolution of normal fault systems. Journal of Structural Geology 5, 471-482.

Kelletat D., Kowalczyk G., Schröder B. and Winter K.P. 1978. Neotectonics in the Peloponnesian coastal regions. In H. Cloos, D. Roeder and K. Schmidt, eds, Alps, Apennines, Hellenides; Schweizerbart, Stuttgart, 512-518.

Keraudren B., 1970. Les formations quarternaires marines de la Grèce. Thesis, Univ. Paris, $382 \mathrm{p}$.

Mistardis G. 1933. Sur les grès quaternaires de l'Attique. C.R. Acad. Sci. Paris 196, 1819-1822.

Philippson A. 1898. La tectonique de l'Egéide. Ann. de Géographie, 7, 112-141.

Philippson A. 1901. Beiträge zur Kenntnis der griechischen Inselwelt. Petermanns Mitteilungen, Erg.H. no 134, $172 p$,

Pirazzoli P., Montaggioni L., Saliege J., Segonzac G., Thommeret Y. and Vergnaud-Grazzini C. 1989. Crustal block movements from Holocene shorelines, Rhodes island (Greece). Tectonophysics 170, 89-114.

Shackleton N. 1987. Oxygen isotopes, ice volume and sea level. Quaternary Science Reviews 6, 183-190.

Skene K.I., Piper D.J.W., Aksu A.E. and Syvitski J.P. 1998. Evaluation of the global oxygen isotope curve as a proxy for Quaternary sea level by modelling of delta progradation. J. sedim. Res. 68, 1077-1092.

Stiros S., Arnold M., Pirazzoli P., Laborel J., Laborel F. and Papageorgiou S. 1992. Historical co-seismic uplift on Euboea island, Greece. Earth and Planetary Science Letters 108, 109-117.

Voreadis G. 1961. Die Geologie und die Barytlagerstätten der Insel Mykonos. Annales géologiques des pays helléniques $12,263-300$. 